\title{
Interaction between nanoparticles generated by zinc chloride treatment and oxidative responses in rat liver
}

This article was published in the following Dove Press journal:

International Journal of Nanomedicine

27 December 2013

Number of times this article has been viewed

\author{
Inès Azzouz \\ Hamdi Trabelsi \\ Amel Hanini \\ Soumaya Ferchichi \\ Olfa Tebourbi \\ Mohsen Sakly \\ Hafedh Abdelmelek \\ Laboratory of Integrative Physiology, \\ Faculty of Sciences of Bizerte, \\ Carthage University, Tunisia
}

\begin{abstract}
The aim of the present study was to investigate the interaction of zinc chloride (3 $\mathrm{mg} / \mathrm{kg}$, intraperitoneally [ip]) in rat liver in terms of the biosynthesis of nanoparticles. Zinc treatment increased zinc content in rat liver. Analysis of fluorescence revealed the presence of red fluorescence in the liver following zinc treatment. Interestingly, the co-exposure to zinc ( $3 \mathrm{mg} / \mathrm{kg}$, ip) and selenium $(0.20 \mathrm{mg} / \mathrm{L}$, per os [by mouth]) led to a higher intensity of red fluorescence compared to zinc-treated rats. In addition, X-ray diffraction measurements carried out on liver fractions of zinc-treated rats point to the biosynthesis of zinc sulfide and/or selenide nanocomplexes at nearly $51.60 \mathrm{~nm}$ in size. Moreover, co-exposure led to nanocomplexes of about $72.60 \mathrm{~nm}$ in size. The interaction of zinc with other mineral elements (S, Se) generates several nanocomplexes, such as $\mathrm{ZnS}$ and/or ZnSe. The nanocomplex ZnX could interact directly with enzyme activity or indirectly by the disruption of mineral elements' bioavailability in cells. Subacute zinc or selenium treatment decreased malondialdehyde levels, indicating a drop in lipid peroxidation. In addition, antioxidant enzyme assays showed that treatment with zinc or co-treatment with zinc and selenium increased the activities of glutathione peroxidase, catalase, and superoxide dismutase. Consequently, zinc complexation with sulfur and/or selenium at nanoscale level could enhance antioxidative responses, which is correlated to the ratio of number of $\mathrm{ZnX}$ nanoparticles ( $\mathrm{X}=$ sulfur or $\mathrm{X}=$ selenium) to malondialdehyde level in rat liver.
\end{abstract}

Keywords: nanocomplexes biosynthesis, antioxidative responses, X-ray diffraction, fluorescence microscopy, liver

\section{Introduction}

Zinc $(\mathrm{Zn})$ is a ubiquitous and essential trace element in biological systems. The $\mathrm{Zn}$ ion is a catalytic component of many enzymes and plays a structural role in a large number of proteins and transcription factors, controlling cell proliferation, differentiation, and both apoptotic and necrotic cell death. ${ }^{1-3}$ The liver plays a key role in $\mathrm{Zn}$ homeostasis, regulating the incorporation of $\mathrm{Zn}$ ions in a large variety of enzymes which play a central function in the metabolism of the human body. ${ }^{4} \mathrm{Zn}$ plays an important role in the induction of metallothionein (MT) biosynthesis in the liver and kidneys. ${ }^{5}$ The MTs, a family of low molecular weight and cysteine-rich proteins (20 cysteine residues of a total of 61-68 amino acids), are the most abundant $\mathrm{Zn}$ storage proteins. ${ }^{6}$ The function of $\mathrm{Zn}$ in protecting biological structures from free radical damage may be due to several factors: first, by maintaining an adequate level of MTs, which is also a free radical scavenger; then, as an essential structural component of $\mathrm{CuZn}$-superoxide dismutase (CuZn-SOD); and finally, as a protective agent for thiols and other chemical groups. ${ }^{7}$ Regulation of MT biosynthesis by $\mathrm{Zn}$ has been considered a biological
Correspondence: Inès Azzouz

Laboratoire de Physiologie Intégrée, Faculté des Sciences de Bizerte,

7021 Jarzouna, Tunisia

$\mathrm{Tel}+21622874731$

Fax +21672590566

Email inessazzouz@hotmail.fr
International Journal of Nanomedicine 2014:9 223-229 
device to maintain homeostatic concentrations of essential and non-essential free metal ions by chelation. ${ }^{8}$

In addition, selenium ( $\mathrm{Se}$ ) is an essential trace element for animals and humans that is obtained from dietary sources, including cereals, grains, and vegetables. ${ }^{9}$ Se plays an important role in a number of physiological processes, including the neutralization of reactive oxygen species (ROS) and the modulation of redox-sensitive enzyme cascades. ${ }^{10,11}$

Recently, Trabelsi et al demonstrated that subacute exposure to cadmium $(\mathrm{Cd})$ generates nanocomplexes $(\mathrm{CdS}$ and/or CdSe) at cellular levels in the liver and kidneys. ${ }^{12,13}$ The authors reported that Se decreases the oxidative responses by enhancing the biosynthesis of nanocomplexes (CdSe and/or CdS) in rat nephrocytes. This biosynthesis may represent a detoxification pathway after $\mathrm{Cd}$ treatment. Hence, the biosynthesis of nanoparticles ameliorates the oxidative responses and decreases damage caused by cadmium in hepatocytes. ${ }^{13}$

The aim of this study was to investigate the eventual interaction between $\mathrm{Zn}$ and sulfur $(\mathrm{S})$ and/or Se at cellular levels in the liver. These interactions could be understood in terms of nanocomplex biosynthesis and the modulation of oxidative responses.

\section{Material and methods Chemicals}

Zinc chloride $\left(\mathrm{ZnCl}_{2}\right)$ and sodium selenite $\left(\mathrm{Na}_{2} \mathrm{SeO}_{3}\right)$ were purchased from Sigma-Aldrich (St Louis, MO, USA). All other chemicals were of analytical grade and were purchased from Chemi-pharma (Le Bardo, Tunisia).

\section{Animals}

Adult Wistar male rats (SIPHAT, Bin Arous, Tunisia), weighing 180-200 $\mathrm{g}$ at the time of the experiments were randomly divided into the following groups: control rats $(n=6)$, zinc-treated rats $(\mathrm{Zn})(\mathrm{n}=6)$, and co-treated rats $(\mathrm{Zn}+\mathrm{Se})(\mathrm{n}=6)$. Animals were housed at $25^{\circ} \mathrm{C}$, under a 12-hour/12-hour light/dark cycle, with free access to water and commercial mash. Animals were cared for under the Tunisian code of practice for the Care and Use of Animals for Scientific Purposes. The experimental protocols were approved by the Faculty Ethics Committee (Faculté des Sciences de Bizerte, Tunisia).

\section{Animal treatment}

The control group was intraperitoneally (ip) injected with $0.10 \mathrm{~mL}$ of $0.90 \%$ saline solution for 14 consecutive days. The zinc-treated group was intraperitoneally injected with zinc chloride ( $3 \mathrm{mg} / \mathrm{kg}$ of body weight) for 14 days. The co-exposed rats were treated with zinc $(3 \mathrm{mg} / \mathrm{kg}$ of body weight) and selenium (0.20 mg/L, per os [by mouth]) for 14 days. ${ }^{10}$

\section{Zinc determination}

Liver slices for $\mathrm{Zn}$ analyses were oven-dried $\left(60^{\circ} \mathrm{C}\right)$ to a constant weight. The dried tissues $(100 \mathrm{mg}$ from each sample) were digested with $3 \mathrm{~mL}$ trace pure nitric acid at $120^{\circ} \mathrm{C}$. The volume was then adjusted to $10 \mathrm{~mL}$ with deionized water. $^{14}$

$\mathrm{Zn}$ concentrations in the acid solutions were measured by atomic absorption spectrophotometry using a Perkin Elmer 306 spectrometer (Waltham, MA, USA) equipped with a Perkin Elmer Intensitron lamp. Zn concentration was expressed in $\mu \mathrm{g} / \mathrm{g}$ dry tissue weight. ${ }^{15}$

\section{Fluorescence microscopy}

Liver fractions were fixed with 10\% formaldehyde and were evaluated by fluorescence microscopy using a DM-IRBE microscope (Leica Microsystems, Wetzlar, Germany) equipped with a mercury arc lamp (excitation wavelength $=540 \mathrm{~nm}$ ) and coupled with a digital camera (CCD camera CoolSNAPTM; Princeton Instruments, Trenton, NJ, USA). The emission filter was set at $620 \mathrm{~nm}$. Fluorescence images were processed using Leica IM50 software (v5.00). Images were obtained with 40× enlargement. ${ }^{13}$

\section{Powder samples preparation and X-ray diffraction (XRD) measurements}

At 14 days postintraperitoneal injection, the control and treated groups were sacrificed and their livers harvested. The tissues were weighed, rinsed with ice-cold deionized water and dried with filter paper. Liver fractions were dried for 5 days at $50^{\circ} \mathrm{C}$. Fractions were mixed and sieved in order to obtain powder. XRD measurements were carried out on a Bruker D8 advance powder X-ray diffractometer (Billerica, MA, USA), using $\mathrm{Cu} \mathrm{K} \alpha(\lambda=1: 5402 \AA)$ as an incident radiation with a scan range of $20<2 \theta<70 .{ }^{12}$

\section{Tissue preparation}

The control and treated groups were sacrificed and their livers were immediately harvested. The tissues were weighed, rinsed with ice-cold deionized water and dried with filter paper. Fractions of tissues $(500 \mathrm{mg}$ ) were homogenized in buffer (Tris $10 \mathrm{mmol} / \mathrm{L}$, EDTA $1 \mathrm{mmol} / \mathrm{L}$, phenylmethylsulfonyl fluoride (PMSF) $1 \mathrm{mmol} / \mathrm{L} ; \mathrm{pH}=7.40$ ). The homogenates were centrifuged at $600 \times g$ for 10 minutes and recentrifuged 
at $13.000 \times g$ for 20 minutes at $4^{\circ} \mathrm{C}$ to obtain post-nuclear homogenate and post-mitochondrial supernatant fractions. ${ }^{16}$

\section{Antioxidant enzyme assays}

Lipid peroxidation (LPO) in tissues was measured by the thiobarbituric acid-reacting substance (TBARS) method and was expressed in terms of malondialdehyde (MDA) content. ${ }^{17}$ Catalase (CAT) activity was assayed by UV spectrophotometry. ${ }^{18}$ Glutathione peroxidase (GPx) activity was measured according to the method by Gunzler et al. ${ }^{19}$ Superoxide dismutase (SOD) activity was determined by measuring the inhibition of the auto-oxidant of pyrogallol by spectrophotometry (Jenway $6505 \mathrm{UV} / \mathrm{Vis}$, Stone, UK) at $420 \mathrm{~nm}$, using a modification of the method of Marklund and Marklund. ${ }^{20}$

\section{Data presentation and statistical analysis}

One-way analysis of variance (ANOVA) followed by Tukey's multiple comparisons test was performed using GraphPad Prism (v6.00 for Windows; GraphPad Software, Inc, La Jolla, CA, USA). Data is reported as the mean $\pm \mathrm{SD}$ and the level of significance was set at $P<0.05$.

\section{Results}

\section{Zinc accumulation in liver}

Figure 1 shows an accumulation of zinc in the liver in comparison to the control $(478.85 \pm 9.57$ vs $345.19 \pm 7.16 \mu \mathrm{g} / \mathrm{g}$, $P<0.01)$. By contrast, selenium supplementation $(0.20 \mathrm{mg} / \mathrm{L}$, per os) reduced zinc accumulation compared to values found in zinc-treated rats $(478.85 \pm 9.57$ vs $411.13 \pm 7.13 \mu \mathrm{g} / \mathrm{g}$, $P<0.05)$.

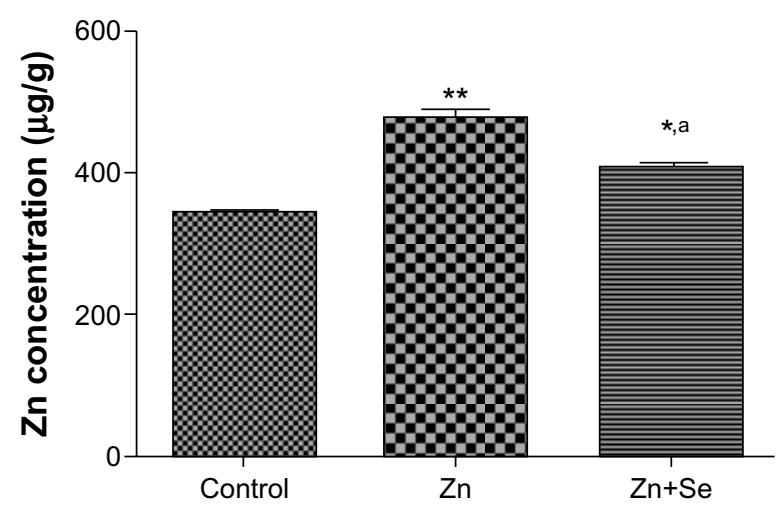

Figure I Zn concentration in liver of control rats, Zn-treated rats ( $3 \mathrm{mg} / \mathrm{kg}$, ip), and co-exposed rats to $\mathrm{Zn}$ and Se (Zn: $3 \mathrm{mg} / \mathrm{kg}$ ip and Se: $0.20 \mathrm{mg} / \mathrm{L}$ per os [by mouth]). Notes: Data represent the means \pm SD of six animals per group; $* P<0.05$ and $* * P<0.0$ I compared with the control group; $\mathrm{a}<0.05$ compared to the zinc-treated group.

Abbreviation: ip, intraperitoneally.

\section{Fluorescence microscopy}

Fluorescence microscopy images showed no fluorescence signals in control livers (Figure 2A and B). However, red fluorescence was detected in the livers of zinc-treated rats (Figure 2C and D). Interestingly, the intensity of the fluorescence signal was higher after co-treatment with $\mathrm{Zn}$ and $\mathrm{Se}$ compared to the zinc-treated group (Figure 2E and F).

\section{X-ray diffraction pattern}

The XRD pattern of liver powder harvested from zinctreated rats revealed three new peaks observed at $2 \theta=23.98^{\circ}$, $2 \theta=30.79^{\circ}$, and $2 \theta=46.52^{\circ}$, referring to the diffraction of cubic (zinc blende), zinc sulfide ( $\mathrm{ZnS}$ ), and/or zinc selenide $(\mathrm{ZnSe})$ nanocomplexes, respectively. The XRD pattern of co-treated rats showed three new peaks compared to the control (Figure 3). New peaks were observed at $2 \theta=25.54^{\circ}$, $2 \theta=42.95^{\circ}$, and $2 \theta=50.04^{\circ}$, referring to the diffraction of cubic (zinc blende), zinc sulfide, and/or zinc selenide nanocomplexes, respectively. The size was determined from the full width at half maximum (FWHM) of the most intense peak using the Scherrer equation [1].

$$
\mathrm{D}=0.9 \lambda / \beta \cos \theta
$$

where $\lambda$ is the wavelength of the $X$-ray radiation, $\beta$ is the FWHM in radians of the XRD peak, and $\theta$ is the angle

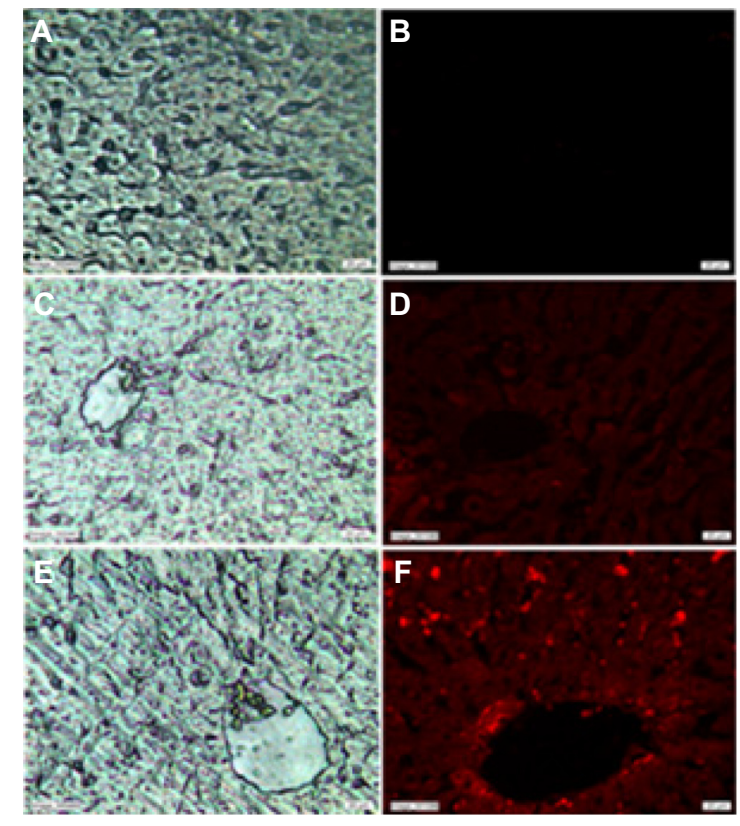

Figure 2 Light microscopy (A) and fluorescence microscopy images (B) of the liver of control rats. Light microscopy (C) and fluorescence microscopy images (D) of the liver of zinc-treated rats $(3 \mathrm{mg} / \mathrm{kg}$, ip). Light microscopy $(\mathbf{E})$ and fluorescence microscopy images (F) of the liver of co-exposed rats to $Z n$ and Se $(Z n: 3 \mathrm{mg} / \mathrm{kg}$ ip and Se: $0.20 \mathrm{mg} / \mathrm{L}$, per os [by mouth]).

Abbreviation: ip, intraperitoneally. 


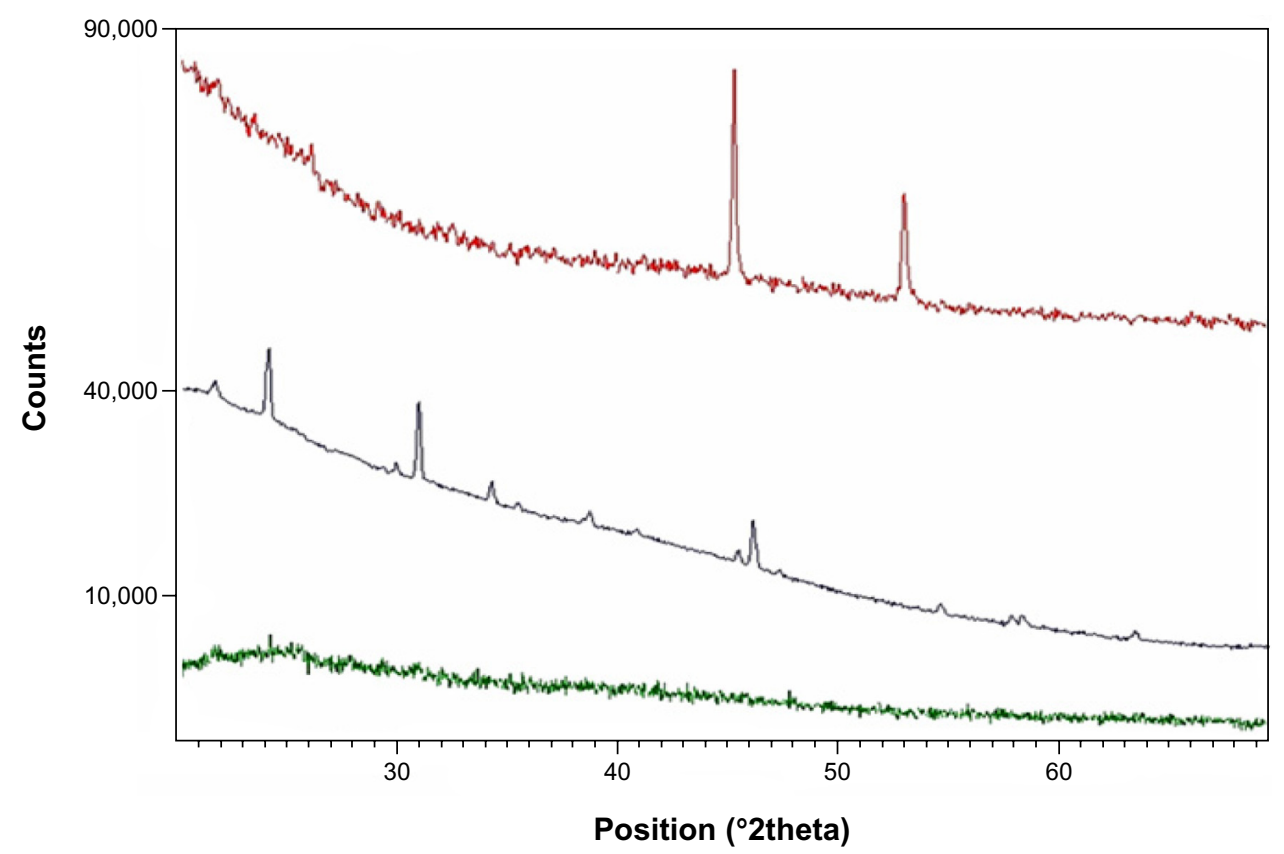

Figure $3 \mathrm{X}$-ray diffraction pattern from liver fractions powder of control rats (green pattern), zinc-treated rats ( $3 \mathrm{mg} / \mathrm{kg}$, ip) (black pattern), and co-treated rats with Zn and Se (Zn: $3 \mathrm{mg} / \mathrm{kg}$, ip and Se: $0.20 \mathrm{mg} / \mathrm{L}$, per os [by mouth]) (red pattern).

Abbreviation: ip, intraperitoneally.

of diffraction. The average $\mathrm{ZnS}$ and/or $\mathrm{ZnSe}$ nanocomplex size is determined to be about $51.60 \mathrm{~nm}$ for the zinc-treated group and $72.60 \mathrm{~nm}$ for the co-exposed group to zinc and selenium $(\mathrm{Zn}+\mathrm{Se})$.

\section{Oxidative responses assays MDA concentration}

Results showed that rats treated with $\mathrm{Zn}$ displayed a decrease in MDA $(0.43 \pm 0.01$ vs $0.57 \pm 0.02 \mathrm{nmol} / \mathrm{mg}$ protein, $P<0.05)$. In addition, simultaneous administration of $\mathrm{Zn}$ and Se induced a decrease in MDA level compared to the control group $(0.22 \pm 0.02$ vs $0.57 \pm 0.01 \mathrm{nmol} / \mathrm{mg}$ protein, $P<0.001)$ and compared to the zinc-treated group $(0.22 \pm 0.02 \mathrm{vs}$ $0.43 \pm 0.01 \mathrm{nmol} / \mathrm{mg}$ protein, $P<0.01$ ) (Figure 4).

\section{Antioxidant enzyme activity in the liver}

Zinc administration led to an increase of CAT (71.89 \pm 1.68 vs $66.12 \pm 1.82 \mathrm{U} / \mathrm{mg}$ protein, $P<0.05)$, SOD $(43.68 \pm 1.54 \mathrm{vs}$ $27.73 \pm 0.87 \mathrm{U} / \mathrm{mg}$ protein, $P<0.05$ ), and $\mathrm{CuZn-SOD}$ $(25.71 \pm 0.72$ vs $18.10 \pm 0.19 \mathrm{U} / \mathrm{mg}$ protein, $P<0.05)$ activities. In addition, co-treatment with $\mathrm{Zn}$ and Se enhanced GPx, CAT, SOD, CuZn-SOD, FeMn-SOD, and Mn-SOD activities compared to the control and zinc-treated groups (Table 1).

\section{Discussion}

In our study, Wistar male rats were intraperitoneally treated with zinc chloride ( $3 \mathrm{mg} / \mathrm{kg}$ of body weight) and received selenium $(0.20 \mathrm{mg} / \mathrm{L}$, per os $)$ in drinking water in order to better explain the interaction at the nanoscale level between mineral elements and oxidative responses in rat liver.

Our results showed that subacute treatment with zinc ( $\mathrm{Zn}$ group) and co-treatment with zinc $(\mathrm{Zn})$ and selenium (Se) ( $\mathrm{Zn}+\mathrm{Se}$ group) induced an increase in liver zinc content compared to the controls (Figure 1). This finding is in agreement with previous studies. ${ }^{21,22}$ Importantly, selenium supplementation reduced the zinc content in the liver of co-exposed rats compared to zinc-treated rats. This fall of $\mathrm{Zn}$ in the liver may be explained by the complexation of $\mathrm{Zn}$

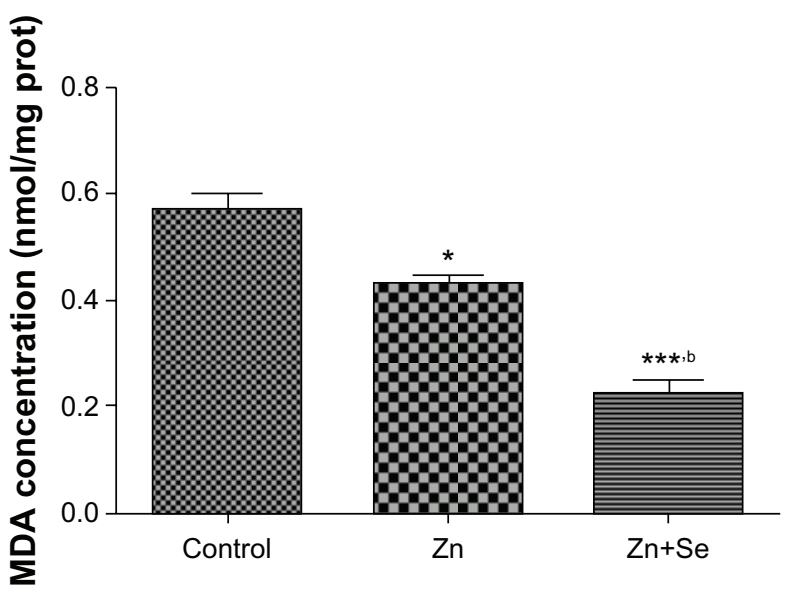

Figure 4 Effects of zinc and selenium on hepatic malondialdehyde level in rats. Notes: Data represent the mean \pm SD of six animals per group; $* P<0.05$, $* * * P<0.00$ I compared to the control group; ${ }^{b} P<0.01$ compared to the zinc-treated group. Abbreviations: MDA, malondialdehyde; prot, protein. 
Table I Effects of zinc and selenium treatments on antioxidant enzyme activity in rat liver

\begin{tabular}{lllllll}
\hline & GPx & CAT & SOD & CuZn-SOD & FeMn-SOD & $\begin{array}{l}\text { Mn-SOD } \\
\text { (U/mg prot) }\end{array}$ \\
\hline (U/mg prot) & (U/mg prot) & (U/mg prot) & (U/mg prot) & (U/mg prot) & $1.59 \pm 0.06$ \\
$Z n$ & $1,311 \pm 60.69$ & $66.12 \pm 1.82$ & $27.73 \pm 0.87$ & $18.10 \pm 0.19$ & $13.98 \pm 0.12$ & $12.71 \pm 0.46$ \\
$Z n+S e$ & $1,468 \pm 12.70$ & $71.89 \pm 1.68^{*}$ & $43.68 \pm 1.54^{*}$ & $25.71 \pm 0.72^{*}$ & $1.06 \pm 0.02$ \\
\hline
\end{tabular}

Notes: Data represents the mean $\pm S D$ of six animals per group; ${ }^{*} P<0.05$; ${ }^{* * P}<0.0$ I; ${ }^{\mu} P<0.000$ I compared to the control; ${ }^{a} P<0.05$; ${ }^{b} P<0.01$; ${ }^{c} P<0.00$ I; ${ }^{d} P<0.000$ I compared to the zinc-treated group.

Abbreviations: CAT, catalase; C, control group; CuZn-SOD, copper/zinc superoxide dismutase; FeMn-SOD, iron/manganese superoxide dismutase; GPx, glutathione peroxidase; Mn-SOD, manganese superoxide dismutase; prot, protein; SOD, superoxide dismutase.

with MTs; leading to the redistribution of this complex from the liver to the kidneys. ${ }^{2,23}$

Fluorescence microscopy images showed that zinc treatment induced a red fluorescence signal in rat liver compared to the controls (Figure 2). This finding may be explained by the nanocomplexation of this metal with sulfur from MTs or selenium at the nanoscale level leading to fluorescent nanocomplexes. In fact, zinc is known to induce the synthesis of MTs, a family of cysteine-rich low molecular weight proteins. ${ }^{24-26} \mathrm{Zn}$ ions are bound by MTs via thiol groups leading to Zn-MTs complexes. In addition, Feroci et al demonstrated that $\mathrm{Zn}$ metal cations generate complexes with a different strength and solubility in the presence of selenite anions. ${ }^{27}$

Interestingly, Trabelsi et al showed that $\mathrm{Cd}$ may induce nanoparticle biosynthesis in the liver and kidneys. ${ }^{12}$ The authors explained this biosynthesis by the ability of $\mathrm{Cd}$ to react with sulfur in MTs and/or with Se, leading to CdS and/or CdSe nanoparticles. Trabelsi et al reported that the interaction of $\mathrm{Cd}$ with some kidneys elements could generate red fluorescent quantum dots like $\mathrm{CdS}$ and/or CdSe. ${ }^{13}$

Fluorescence microscopy images showed that cotreatment with zinc and selenium enhanced the intensity of the red fluorescence signal in rat liver compared to the zinc-group. The origin of these fluorescence signals can be explained by the biosynthesis of $\mathrm{ZnS}$ and/or ZnSe nanoparticles in rat liver. In fact, $\mathrm{ZnSe}$ and $\mathrm{ZnS}$ quantum dots are characterized by size-dependent photoluminescence colors, which were distributed throughout the visible region of the electromagnetic spectrum. ${ }^{28,29}$

In order to confirm the hypothesis of nanocomplex synthesis, XRD measurements of liver powder fractions were performed (Figure 3). Interestingly, our results showed that $2 \theta$ values are almost the same compared to those observed after chemical synthesis of $\mathrm{ZnS}$ and/or ZnSe nanoparticles as reported in many studies. ${ }^{30-33}$ Differences observed in $2 \theta$ values compared to chemical synthesis may be due to the temperature variation from high temperatures during the chemical synthesis to the lower rat body temperature (about $37^{\circ} \mathrm{C}$ ). In fact, the size uniformity distribution and size average can be affected by a temperature synthesis variation of even less than $1^{\circ} \mathrm{C},{ }^{34}$ which has also been reported in other studies. ${ }^{34,35}$ The broadening of diffraction peaks gives information about the crystallite size. As width increases, the particle size decreases; while as width decreases, particle size increases. ${ }^{36}$ In our investigation, the size of nanocomplexes found in the liver $(51.60 \mathrm{~nm}$ for the zinc-treated group and $72.60 \mathrm{~nm}$ for co-treated rats with zinc and selenium) indicates a probable agglomeration of the biosynthesized nanocomplexes.

The interaction of zinc with other mineral elements $(\mathrm{S}, \mathrm{Se})$ generates several complexes like $\mathrm{ZnX}(\mathrm{X}=\mathrm{S}, \mathrm{X}=\mathrm{Se})$. The nanocomplex $\mathrm{ZnX}$ could interact directly with activity of enzymes or indirectly by the disruption of mineral elements' bioavailability in cells leading to a dysfunction of the biosynthesis of enzyme co-factors. In order to investigate the interaction of $\mathrm{ZnS}$ and/or $\mathrm{ZnSe}$ nanoparticles with oxidative responses; lipid peroxidation and antioxidant enzyme activity were investigated (Figure 4 and Table 1). The present results have clearly demonstrated the ability of Zn to improve antioxidant responses in rat liver, as evidenced by the increased SOD, CAT, and GPx activities. The same treatment decreased MDA levels after 14 days of $\mathrm{Zn}$ administration, indicating its inhibitory effect on lipid peroxidation.

In fact, zinc is an essential trace mineral that acts as an antioxidant by neutralizing free radical generation. ${ }^{2,37}$ Souza et al suggested that $\mathrm{Zn}$ protection may be related to the maintenance of normal redox balance inside cells. ${ }^{38} \mathrm{Zn}$ could exert a direct antioxidant action by occupying the iron or copper binding sites of lipids, proteins, and DNA. ${ }^{39}$ It has been noted that zinc has a relationship with many enzymes in the body and can prevent cell damage through activation of the antioxidant system. ${ }^{37,40-42}$ One study has shown that $\mathrm{Zn}$ deficiency in the diet paved the way for cell damage. ${ }^{43}$ Furthermore, $\mathrm{Zn}$ deficiency increased the lipid peroxidation in various rat tissues, whereas $\mathrm{Zn}$ supplementation corrected the impairment. ${ }^{41,44}$ 
Additionally, co-treatment with $\mathrm{Zn}$ (3 mg/kg, ip) and Se $(0.20 \mathrm{mg} / \mathrm{L}$, per os $)$ decreased MDA compared to the control and zinc-treated groups. This finding is correlated to the increased GPx, CAT, and SOD activities in the liver of co-exposed rats. The observed decrease of MDA concentration in co-treated group is in agreement with previous investigations and can be explained by the enhanced activities of SOD and GPx. ${ }^{45-47}$ In fact, $\mathrm{Zn}$ and Se are involved in many biochemical processes supporting life. The most important of these processes are maintenance of cell membrane integrity and sequestration of free radicals. $\mathrm{Zn}$ and Se are involved in the destruction of free radicals through cascading enzyme systems. Superoxide radicals are reduced to hydrogen peroxide by SODs in the presence of $\mathrm{Zn}$ cofactors. Hydrogen peroxide is then reduced to water by the Se-GPx couple. Efficient removal of these superoxide free radicals maintains the integrity of membranes and prevents lipid peroxidation. ${ }^{48}$ Se effect on GPx activity may be attributed to an increase in the bioavailability of Se following co-treatment with sodium selenite, which is reflected in the increased GPx activity. ${ }^{46}$

Interestingly, as far as we know, our investigation reported for the first time that interaction of zinc with sulfur and selenium ameliorates oxidative responses by enhancing the nanocomplexation between these elements in rat liver. Therefore, as $\mathrm{ZnS}$ and/or ZnSe nanoparticles biosynthesis increases in liver, red fluorescence increases, and the activities of antioxidant enzymes are enhanced at the same time. This finding can be explained by the following ratio:

$$
\frac{\text { Number of ( } \mathrm{ZnX}) \text { nanoparticles }}{\text { Pro-oxidant marker (MDA level) }}
$$

where $\mathrm{X}$ refers to sulfur and/or selenium. According to this ratio, the decrease in MDA level is concomitant to the increase in the $(\mathrm{ZnX})$ nanoparticle number. A similar result was previously described by Trabelsi et al. ${ }^{13}$

\section{Conclusion}

In conclusion, our results showed for the first time, as far as we know, that the interaction of zinc with sulfur and or selenium in rat liver may induce biosynthesis of red emitting $\mathrm{ZnS}$ and/or $\mathrm{ZnSe}$ nanoparticles. Our study showed also that co-treatment with zinc and selenium ameliorated oxidative responses in rat liver and enhanced the red fluorescence signal compared to zinc-treated rats. The enhanced red fluorescence is concomitant to an increase in antioxidative enzyme activity.

\section{Acknowledgments}

We would like to thank Dr Ahmed Rejeb (Department of Anatomic Pathology, Ecole Nationale de Médecine Vétérinaire, Sidi Thabet, Tunisia) and Mr Hazem Ben Mabrouk (Institut Pasteur de Tunis, Tunisia) for their help in the fluorescence microscopy work.

\section{Disclosure}

The authors report no conflicts of interest in this work.

\section{References}

1. Maret W. Zinc coordination environments in proteins determine zinc functions. J Trace Elem Med Biol. 2005;19:7-12.

2. Amara S, Abdelmelek H, Garrel C, et al. Zinc supplementation ameliorates static magnetic field-induced oxidative stress in rat tissues. Environ Toxicol Pharmacol. 2007;23:193-197.

3. Rogalska J, Pilat-Marcinkiewicz B, Brzóska MM. Protective effect of zinc against cadmium hepatotoxicity depends on this bioelement intake and level of cadmium exposure: a study in a rat model. Chem Biol Interact. 2011;193:191-203.

4. Faa G, Nurchi VM, Ravarino A, et al. Zinc in gastrointestinal and liver disease. Coordina Chem Rev. 2008;252:1257-1269.

5. Sargazi M, Shenkin A, Roberts NB. Zinc induced damage to kidney proximal tubular cells: studies on chemical speciation leading to a mechanism of damage. J Trace Elem Med Biol. 2013;27:242-248.

6. Oteiza PI. Zinc and the modulation of redox homeostasis. Free Radic Biol Med. 2012;53:1748-1759.

7. Jemai H, Messaoudi I, Chaouch A, Kerkeni A. Protective effect of zinc supplementation on blood antioxidant defense system in rats exposed to cadmium. J Trace Elem Med Biol. 2007;21:269-273.

8. Winge DR, Dameron CT. The metallothionein structural motif involved in metalloregulation. In: Suzuki KT, Imura N, Kimura M, editors. Metallothionein III. Basel: Birkhaüser Verlag; 1993:381-397.

9. Tapiero H, Townsend DM, Tew KD. The antioxidant role of selenium and seleno compounds. Biomed Pharmacother. 2003;57:134-144.

10. Ghodbane S, Amara S, Garrel C, et al. Selenium supplementation ameliorates static magnetic field-induced disorders in antioxidant status in rat tissues. Environ Toxicol Pharmacol. 2011;31(1):100-106.

11. Viezeliene D, Jansen E, Rodovicius H, Kasauskas A, Ivanov L. Protective effect of selenium on aluminium-induced oxidative stress in mouse liver in vivo. Environ Toxicol Pharmacol. 2011;31:302-306.

12. Trabelsi H, Azzouz I, Sakly M, Abdelemelek H. Subacute toxicity of cadmium on hepatocytes and nephrocytes in rat could be considered as a green biosynthesis of nanoparticles. Int J Nanomedicine. 2013;8: $1121-1128$.

13. Trabelsi H, Azzouz I, Ferchichi S, Tebourbi O, Sakly M, Abdelmelek H. Nanotoxicological evaluation of oxidative responses in rat nephrocytes induced by cadmium. Int J Nanomedicine. 2013;8:3447-3453.

14. Takashima M, Nishino K, Itokawa Y. Effect of cadmium administration on growth, excretion and tissue accumulation of cadmium and histological alterations in calcium-sufficient and deficient rats: an equalized feeding study. Environ Toxicol Pharmacol. 1978;45(2):591-598.

15. Congui L, Chicca M, Pilastro A, Turchetto M, Tallandini L. Effects of chronic dietary cadmium on hepatic glutathione levels and glutathione peroxidase activity in starlings (Sturnus vulgaris). Arch Environ Contam Toxicol. 2000;38(3):357-361.

16. Beytut E, Aksakal M. The effect of long-term supplemental dietary cadmium on lipid peroxidation and the antioxidant system in the liver and kidneys of rabbits. Turk J Vet Anim Sci. 2002;26(5):1055-1060.

17. Placer ZA, Cushman LL, Johnson BC. Estimation of product of lipid peroxidation (malonyl dialdehyde) in biochemical systems. Anal Biochem. 1966;16(2):359-364. 
18. Beers RF Jr, Sizer IW. A spectrophotometric method for measuring the breakdown of hydrogen peroxide by catalase. J Biol Chem. 1952;195(1): 133-140.

19. Gunzler WA, Kremers H, Flohe L. An improved coupled test procedure for glutathione peroxidase in blood. Z Klin Chem Klin Biochem. 1974;12(10):444-448.

20. Marklund S, Marklund G. Involvement of superoxide anion radical in auto-oxidation of pyrogallol and a convenient assay of superoxide dismutase. Eur J Biochem. 1974;47(3):469-474.

21. Shimada H, Yasutake A, Hirashima T, et al. Strain difference of cadmium accumulation by liver slices of inbred Wistar-Imamichi and Fischer 344 rats. Toxicol In Vitro. 2008;22:338-343.

22. Eck P, Pallauf J. Induction of metallothionein by exposure to normobaric $100 \%$ oxygen atmosphere in rats with different zinc supply. J Trace Elem Med Biol. 2001;15:229-235.

23. Chater S, Douki T, Garrel C, Favier A, Sakly M, Abdelmelek H. Cadmium-induced oxidative stress and DNA damage in kidney of pregnant female rats. $C R$ biol. 2008;331(6):426-432.

24. Iszard MB, Liu J, Klaassen CD. Effect of several metallothionein inducers on oxidative stress defense mechanisms in rats. Toxicology. 1995;104:25-33.

25. Kröncke KD, Klotz LO. Zinc fingers as biologic redox switches? Antioxid Redox Signal. 2009;11:1015-1027.

26. Vasak M, Kagi JHR. Metallothioneins. In: King RB, editor. Encyclopedia of Inorganic Chemistry. New York: Wiley; 1994;4:2229-2241.

27. Feroci G, Badiello R, Fini A. Interactions between different selenium compounds and zinc, cadmium and mercury. J Trace Elem Med Biol. 2005;18:227-234.

28. Murray CB, Norris DJ, Bawendi MG. Synthesis and characterization of nearly monodisperse $\mathrm{CdE}$ ( $\mathrm{E}=$ sulfur, selenium, tellurium) semiconductor nanocrystallites. J Am Chem Soc. 1993;115(19):8706-8715.

29. Hines MA, Guyot-Sionnest P. Synthesis and characterization of strongly luminescing ZnS-capped CdSe nanocrystals. J Phys Chem. 1996;100(2):468-471.

30. Maity R, Maiti UN, Mitra MK, Chattopadhyay KK. Synthesis and optical characterization of polymer-capped nanocrystalline $\mathrm{ZnS}$ thin films by chemical process. Physica E. 2006;33:104-109.

31. Moussaoui M, Saoudi R, Lesnichiy IV, Tishchenko AV. Optical measurements of ZnS nanoparticles aqueous solution. J Quant Spectrosc Radiat Transfer. 2011;112:1792-1795.

32. Rajesh C, Lad AD, Ghangrekar A, Mahamuni S. Exciton recombination dynamics in zinc selenide quantum dots. Solid State Commun. 2008;148:435-439.

33. Venkatachalam S, Mangalaraj D, Narayandass SH, Kim K, Yi J. Structure, optical and electrical properties of $\mathrm{ZnSe}$ thin films. Physica B. 2005;358:27-35.
34. Katari JE, Colvin VL, Alivisatos AP. X-ray photoelectron spectroscopy of CdSe nanocrystals with applications to studies of the nanocrystal surface. J Phys Chem. 1994;98(15):4109-4117.

35. Tiwary CS, Kumbhakar P, Mitra AK, Chattopadhyay K. Synthesis of wurtzite-phase ZnS nanocrystal and its optical properties. J Lumin. 2009;129(11):1366-1370.

36. Cullity BD, Stock SR. Elements of X-ray Diffraction. 3rd ed. New Jersey: Prentice Hall; 2001.

37. Powell SR. The antioxidant properties of zinc. J Nutr. 2000;130: 1447-1454.

38. Souza V, Escobar Mdel C, Bucio L, Hernández E, Gutiérrez-Ruiz MC. Zinc pretreatment prevents hepatic stellate cells from cadmiumproduced oxidative damage. Cell Biol Toxicol. 2004;20:241-251.

39. Bray TM, Bettger WJ. The physiological role of zinc as an antioxidant. Free Radic Biol Med. 1990;8:281-291.

40. Ozturk A, Baltaci AK, Mogulkoc R, et al. Effects of zinc deficiency and supplementation on malondialdehyde and glutathione levels in blood and tissue of rats performing swimming exercice. Biol Trace Elem Res. 2003;94:157-166.

41. Ozdemir G, Inanc F. Zinc may protect remote ocular injury caused by intestinal ischemia reperfusion in rats. Tohoku J Exp Med. 2005;206:247-251.

42. Amara S, Abdelmelek H, Garrel C, et al. Preventive effect of zinc against cadmium-induced oxidative stress in the rat testis. $J$ Reprod Dev. 2008;54:129-134.

43. Oteiza PL, Adonayle VN, Keen CL. Cadmium induced testes oxidative damage in rats can be influenced by dietary zinc intake. Toxicology. 1999; 137:13-22.

44. Shaheen AA, El-Fattah AA. Effect of dietary zinc on lipid peroxidation, glutathione, protein levels and superoxide dismutase activity in rat tissues. Int J Biochem Cell Biol. 1995;27:89-95.

45. Chan S, Gerson B, Subramaniam S. The role of copper, molybdenum, selenium, and zinc in nutrition and health. Clin Lab Med. 1998;18(4): 673-685.

46. Jamba L, Nehru B, Bansal MP. Effect of selenium supplementation on the influence of cadmium on glutathione and glutathione peroxidase system in mouse liver. J Trace Elem Exp Med. 2000;13(3):299-304.

47. Klotz LO, Kroncke KD, Buchczyk DP, Sies H. Role of copper, zinc, selenium and tellurium in the cellular defense against oxidative and nitrosative stress. J Nutr. 2003;133(5 Suppl 1):1448S-1451S.

48. Mansour SA, Mossa ATH. Lipid peroxidation and oxidative stress in rat erythrocytes induced by chlorpyrifos and the protective effect of zinc. Pestic Biochem Phys. 2009;93:34-39.
International Journal of Nanomedicine

\section{Publish your work in this journal}

The International Journal of Nanomedicine is an international, peerreviewed journal focusing on the application of nanotechnology in diagnostics, therapeutics, and drug delivery systems throughout the biomedical field. This journal is indexed on PubMed Central,

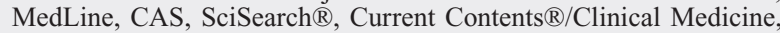

\section{Dovepress}

Journal Citation Reports/Science Edition, EMBase, Scopus and the Elsevier Bibliographic databases. The manuscript management system is completely online and includes a very quick and fair peer-review system, which is all easy to use. Visit http://www.dovepress.com/ testimonials.php to read real quotes from published authors. 